\title{
Economics of Buckwheat Cultivation in the Mainpat Block of Chhattisgarh
}

\author{
Aryama Bharti* and Prishila Kujur \\ Department of Agricultural Economics, Indira Gandhi Krishi Vishwavidayala, \\ Raipur (C.G.) - 492012, India \\ *Corresponding author
}

Keywords

Buckwheat,

Farmers, Cost of cultivation and economics, Inputoutput ratio,

Mainpat,

Chhattisgarh

Article Info

Accepted:

07 November 2019

Available Online:

10 December 2019

\section{A B S T R A C T}

An attempt has been made in this study to examine the economics of production and marketing of buckwheat in Surguja district of Chhattisgarh. The specific objectives of the study were to work out the cost and returns of buckwheat on different categories of selected farmers. The present study was conducted in Mainpat block in Surguja district of Chhattisgarh state. One fifty farmers were selected in Mainpat. Out of 150 farmers, 32 marginal, 36 small, 38 medium and 44 large farmers were selected. The primary data were collected for the year 2015-2016. To calculate the cost of cultivation simple mean and average method was used. The major findings of this study revealed that on an average cost of cultivation per hectare of buckwheat was found Rs. 26726.57 and cost of production per quintal was Rs. 1232.87. The overall yield of buckwheat was found to be 20.80 quintal and input-output ratio of buckwheat was observed as 1:3.24.

\section{Introduction}

Buckwheat (Fagopyrum esculentum Moench) is annual monocarp plant from a group of alternative wheat from family of Polygonaceae, species Fagopyrum. Buckwheat is the most important crop of the mountain regions above $1800 \mathrm{~m}$ elevation (Joshi and Rana, 1999).

Buckwheat (Fagopyrum spp.) is one such underutilized crop, which holds tremendous agronomic and nutritional benefits and that's why chosen for the present study.

Buckwheat highly nutritive and unlike common cereals, which are deficient in lysine, buckwheat has excellent protein quality in terms of essential amino acid composition. Buckwheat grains contain about 52.11 per cent starch, 11-12.55 per cent of the total protein, 8.7 per cent of the pulp, 2.23 per cent oil, 11 per cent water and 1.75 per cent of $\mathrm{N}$ protein (Popović et al., 2013). The most 
important ingredients of this plant are flavonoids (Arsić et al., 2008).

In India, buckwheat is widely grown in the Northeastern states including Sikkim and Arunachal Pradesh and it is also cultivated in Manipur, Nagaland, Meghalaya (West Khasi Hills) and in some areas of the Assam plains. During the period 2010-2011 about 2.113 million ha of buckwheat was sown annually worldwide. Average yield of buckwheat during the monitored period was $913 \mathrm{~kg}$ per ha. Areas and average yield have a rising tendency. The most significant producers of buckwheat in the world are China, Russia and Ukraine. In Serbia, buckwheat is produced on small areas.

In Chhattisgarh buckwheat is mainly grown in Mainpat and some part of Samripat in Surguja and Balrampur district of Chhattisgarh state. Complete grain is used as a nutritive supplement for different stews, while seed flour is used for making bread, cake, noodle, pakora, biscuit and seed is also used for making beverage. The total area of buckwheat in Mainpat block of Surguja district is 1390.0 hectare and production is 21517.20 metric tons (Department of agriculture, Government of Chhattisgarh and Directorate of economics and statistics, Government of Chhattisgarh).

The successful buckwheat growing requires specific knowledge, skill, accuracy and thoroughness in production and marketing. Production of buckwheat plays an important role in improving the economic conditions of farmers, specially marginal and small farmers and meeting the nutritional requirements of the people of India. A study of the buckwheat marketing is necessary to improve the marketing system to aid development and provide efficient services in transfer of farm produce and input from producers to consumers. An efficient marketing system minimizes cost and benefits in all sections of society. Looking to above facts, a study is made to understand the economics of buckwheat.

\section{Materials and Methods}

\section{Sampling design (Fig. 1 and 2)}

The Chhattisgarh state has 27 districts. Among these 27 districts Surguja district has been selected purposely for the study because its area and production is maximum for buckwheat cultivation.

Surguja district having 7 blocks namely, Ambikapur, Lakhanpur, Udaypur, Sitapur, Mainpat, Batouli and Lundra. Out of 7 blocks of Surguja district, Mainpat block was selected purposely for the study because of its highest area under cultivation of buckwheat in Surguja district.

A sample of 150 respondents were selected by using probability proportional to size techniques method subject to condition that at least 10 respondents would be included on sample from each of four categories of farms namely, marginal (0 to 1ha.), small (up to2 ha.), medium (>2 to 4 ha.) and large farmer (above 4 ha.). Thus, 150 farmers were selected according to their land holding from the four village of Mainpat block namely, Narmadapur, Sapnadhar, Lalaya and Gangapur (Table 1).

\section{Method of enquiry and data collection}

The study required primary as well as secondary data. Primary data were collected from farmers through personal interview method with the help of well prepared pretested interview schedule and questionnaire for the year 2015-16 in order to compute the growth rate of area, production and productivity of buckwheat in the study area for the period of (2008-09) to (2015-16). 
Secondary data were collected from sources such as Department of Agriculture Government of Chhattisgarh and Commissioner of Land Records and Settlement and Directorate of Economics and Statistics, Government of Chhattisgarh, Raipur.

\section{Cost of cultivation of buckwheat crop}

To estimate the cost of cultivation of buckwheat crop whole cost is divided into two heads i.e. variable cost and fixed cost. The various cost components like human labour, bullock and machine power, manure and fertilizer, seed, irrigation, plant protection material and chemicals are taken into consideration in order to work out the per hectare variable cost of cultivation. The interest on working capital involved in the cultivation is also computed at the prevailing rate of interest. The cost of cultivation is estimated by using simple mathematical analysis.

To work out the cost of cultivation standard method of were adopted which includes cost $\mathrm{A}_{1}, \mathrm{~B}_{1}$ and $\mathrm{C}_{1}$ (Subba Reddy et al., 2004).

Cost $\mathrm{A}_{1}$ : Consist of following 15 items of costs

Value of hired human labour (permanent \& casual)

Value of owned bullock labour

Value of hired bullock labour

Hired machinery charged

Value of fertilizers

Value of manure (produced on farm and purchased)
Value of seed (both farm-produced and purchased)

Value of insecticides and fungicides.

Irrigation charges (both of the owned \& owned and hired tube wells, pumping sets, etc.).

Canal-water charges

Land revenue, cesses and other taxes

Depreciation on farm implements (both bullock drawn \& worked with human labour)

Depreciation on farm building, farm machinery.

Interest on the working capital.

Miscellaneous expenses (wages of artisans, and repairs to small farm implements)

Cost $A_{2}=$ Cost $A_{1}+$ Rent paid for Leased in Land.

Cost $\mathrm{B}_{1}=$ Cost $\mathrm{A}_{1}+$ Interest on value of Owned fixed Capital assets (excluding land)

Cost $\mathrm{B}_{2}=$ Cost $\mathrm{B}_{1}+$ rental value of owned land (Net of land revenue) and rent paid for leased in land.

Cost $\mathrm{C}_{1}=$ Cost $\mathrm{B}_{1}+$ Imputed value of family labour. Cost $C_{2}=$ Cost $B_{2}+$ Imputed value of family labour.

Cost $\mathrm{C}_{3}=$ Cost $\mathrm{C}_{2}+$ Value of management input at $10 \%$ of $\operatorname{Cost} \mathrm{C}_{2}$.

Income over cost $A_{1}=$ Output Value - Cost $\mathrm{A}_{1}$

Income over cost $\mathrm{A}_{2}=$ Output Value $-\operatorname{Cost} \mathrm{A}_{2}$ 
Income over cost $\mathrm{B}_{2}=$ Output Value $-\operatorname{Cost} \mathrm{B}_{1}$

Income over cost $\mathrm{B}_{2}=$ Output Value $-\operatorname{Cost} \mathrm{B}_{2}$

Income over cost $\mathrm{C}_{1}=$ Output Value $-\operatorname{Cost} \mathrm{C}_{1}$

Income over cost $\mathrm{C}_{2}=$ Output Value $-\operatorname{Cost} \mathrm{C}$

Income over cost $\mathrm{C}_{3}=$ Output Value $-\operatorname{Cost} \mathrm{C}$

\section{Family human labour}

The value of family human labour used on the farm was imputed at the hiring wage rates prevailing in the area.

\section{Bullock labour}

Own bullock labour was charged at the hiring rates for bullock pair prevailing in the locality.

\section{Seed}

The cost of home grown seeds was calculated at the market rates prevailing in the area at the time of sowing.

\section{Manures}

Farm yard manures produced on the farm are valued at the prevailing rates in the locality (i.e. per cart load basis). Purchased manures are charged at the actual prices paid plus transportation cost. The residual effect of the farm manures has been ignored.

\section{Fertilizers}

Fertilizer, such as Iffco, Urea are charged at the actual price paid plus transportation cost.

\section{Irrigation charges}

The cost under this head is exclusively related to irrigate crops. The actual source of irrigation is canal, tanks and nala. The days of human labour put in for irrigation are taken into account as irrigation charges.

\section{Land revenue and other cases}

The land revenue and other cases were apportioned among the crops followed on the basis of the proportionate area under crops and their duration.

\section{Rental value of land}

The rental value of land was calculated based on prevailing rates in the study area.

\section{Interest on working capital}

The rate of interest charged was five per cent for working capital i.e. items of cost A and charged for half of the growing season of the crop.

Interest on fixed capital i.e. farm building, machinery, livestock excluding land was charged at the rate of eight per cent.

\section{Depreciation on machinery and implements}

Depreciation is the decrease in the value of permanent assets through wear and tear. Straight lines method was used for calculating depreciation.

The uniform rate of 10 per cent on the total value of machinery, farm implements, farm buildings and livestock charged and only the proportionate charges were allocated to paddy crop on hectare basis.

\section{Evaluation of output}

Farm produce is evaluated at the actual price received by the farmers. Unsold produce is evaluated at the price fixed by government of Chhattisgarh state. 
Measures of comparison (Acharya and Agarwal, 2011)

The following measures of comparison have been adopted:

Cost of cultivation per hectare.

Net income per hectare.

Cost of production per quintal.

Material cost per hectare.

Input-output ratio.

Income analysis.

\section{Cost of cultivation per hectare}

Cost of cultivation per hectare at the different cost concepts has been worked out for the sample holdings. It is worked out by dividing the total cost by the area under the crops.

\section{Net income per hectare}

Net income per hectare at the different cost concepts has been worked out by deducting the respective costs from the gross monetary returns per hectare.

\section{Material cost per hectare}

Material cost concept has been introduced recently. Material cost includes seeds, manures, fertilizers, irrigation and plant protection chemicals etc.

\section{Cost of production per quintal}

The average cost of production per quintal has been worked out by dividing the cost (i.e. Cost $A_{1}$, Cost $B_{1}$ and Cost $C_{1}$, respectively) by total output.

\section{Input-output ratio}

Input-output ratio indicates the efficiency of input. It is computed as under:

Input-output ratio $=$ Gross return $\div$ Total input cost

\section{Results and Discussion}

\section{Economics of buckwheat production (Table 2)}

The economics of buckwheat crop is presented in table 2. It clearly shows that the cost of cultivation per hectare of buckwheat was higher on large farms as compared to marginal farms. Over all, on an average the cost of cultivation per hectare of buckwheat was found to be Rs. 26726.57 per hectare. The cost of cultivation in case of large farm was higher (Rs.27328.31/ha.) as compared to marginal farms (Rs. 24489.28 /ha.), small (Rs.25813.16 /ha.) and medium farms (Rs. 26429.24/ha.).

The cost of cultivation per hectare showed a rising trend with the increase in size of farm. It was due to the fact that the large farmers incurred more expenditure on modern farm inputs like quality seed, fertilizer, plant protection material, hired labour etc. as a result of borrowing from credit institutions and better economic status compared to marginal, small and medium farmers. The higher expenditure returns into higher yield and returns on large farms as compare to others.

Among different input operation on an overall, the per hectare cost was observed highest for total human labour Rs. 8324.011 followed by manures and fertilizer Rs. 4887.25, seed Rs. 2988.87, Machine power Rs. 1966.61, Depreciation Rs. 1136.65, Bullock labour Rs. 219.35, and land revenue Rs.12. 


\section{Yield and cost of production per quintal}

The yield, value of output per hectare and cost of production per quintal of buckwheat on the sample farms have been worked out in table 3 and figure 3. An overall yield per hectare of buckwheat came to 20.8 quintals on the sample farms per hectare which ranges from 19.05 quintal per hectare at marginal farms to 21 quintal per hectare at large farms. The per quintal cost of production, on an overall, is worked out as Rs. 1232.87. The per quintal cost of production of buckwheat is estimated as Rs. 1285.53, Rs. 1290.66, Rs. 1281.11 and Rs.1301.35 at shows that per quintal cost of production is increasing marginal, small, medium and large farm respectively. It decreased with the increased in the size of farms due to higher yield in return to the cost of cultivation on the large farms. The overall value of output per hectare come to Rs. 83200 the value of output per hectare come to Rs. 76200, Rs. 80000 , Rs. 82520, and Rs. 84000 on marginal, small, medium and large farms respectively. The higher value of output on large farms was associated with the higher expenditure incurred on modern farm inputs.

\section{Measures of farm profit}

The overall gross return is observed as Rs. 83200 per hectare in the study area which ranges from Rs. 76200 per hectare at marginal farms, to Rs. 84000 per hectare at large farms. The gross return depends upon variety, productivity and price received by the farmers. The overall net return is observed as Rs. 565553.43 per hectare. It is estimated as Rs. 51710.72 per hectare, Rs. 54186.84 per hectare, Rs. 56090 per hectare and Rs. 56671.59 per hectare at marginal, small, medium and large farms respectively. The overall input-output ratio is observed as 1:3.24 and it varied from 1:3.11 at marginal farms to 1:3.07 at large farms.

\section{Cost and returns on the basis of different cost concept}

The cost and returns on the basis of cost concept in the production of buckwheat have been presented in the table 4 . It is envisaged that Cost A1, as designated the variable cost, depreciation and land revenue of own land was found to be Rs. 25643.53 per hectare an overall basis, which was added of rent paid for lease in land and dignified with Cost A2, found to be Rs. 30643.53 per hectare, indicates the interest on fixed capital imputed with cost B1 Rs. 26571.87 rental value of own land Rs. 5000 per hectare prevailed in the study. Normally, farmers are cultivating the crop in their own land but it has imputed value of land of Rs. 5000 notified Cost B2 was Rs. 31571.87 per hectare. The Cost $\mathrm{C} 1$, found to be Rs. 29298.70 per hectare, includes the value of cost B1 and imputed value of family labour was found to be Rs. 2726.831 per hectare,

Table.1 Number of sample households under different categories in the study area

\begin{tabular}{|c|c|c|c|}
\hline S. No. & Particulars & Number of selected households & Per cent \\
\hline $\mathbf{1}$ & Marginal & 32 & 21.33 \\
\hline $\mathbf{2}$ & Small & 36 & 24.01 \\
\hline $\mathbf{3}$ & Medium & 38 & 25.33 \\
\hline $\mathbf{4}$ & Large & 44 & 29.33 \\
\hline & Total & $\mathbf{1 5 0}$ & $\mathbf{1 0 0}$ \\
\hline
\end{tabular}


Table.2 Costs of cultivation of buckwheat on different farm size

\begin{tabular}{|c|c|c|c|c|c|}
\hline Particular & Marginal & Small & Medium & Large & Overall \\
\hline \multicolumn{6}{|l|}{ A. Material cost } \\
\hline \multirow[t]{2}{*}{ Seed } & 2936.26 & 2995.93 & 2997.23 & 3000 & 2988.878 \\
\hline & (11.99) & $(11.61)$ & $(11.34)$ & $(10.98)$ & $(11.18)$ \\
\hline \multirow[t]{2}{*}{ Manures and fertilizer } & 4819.88 & 4920.8 & 4942.98 & 4968.73 & 4887.256 \\
\hline & (19.68) & (19.06) & $(18.70)$ & (18.18) & (18.29) \\
\hline \multirow[t]{2}{*}{ Plant protection } & 0 & 0 & 0 & 0 & 0 \\
\hline & $(0.00)$ & $(0.00)$ & $(0.00)$ & $(0.00)$ & $(0.00)$ \\
\hline \multirow[t]{2}{*}{ Irrigation charges } & 0 & 0 & 0 & 0 & 0 \\
\hline & $(0.00)$ & $(0.00)$ & $(0.00)$ & $(0.00)$ & $(0.00)$ \\
\hline \multirow[t]{2}{*}{ Intercultural operation } & 0 & 0 & 0 & 0 & 0 \\
\hline & $(0.00)$ & $(0.00)$ & $(0.00)$ & $(0.00)$ & $(0.00)$ \\
\hline \multirow[t]{2}{*}{ Miscellaneous } & 100 & 120 & 180 & 200 & 180.73 \\
\hline & $(0.41)$ & $(0.46)$ & $(0.68)$ & $(0.73)$ & $(0.68)$ \\
\hline \multirow[t]{2}{*}{ Total material cost } & 7856.14 & 8036.73 & 8120.21 & 8168.73 & 8056.864 \\
\hline & $(32.07)$ & $(31.13)$ & $(30.72)$ & $(29.89)$ & $(30.14)$ \\
\hline \multicolumn{6}{|c|}{ B. Human labour cost } \\
\hline \multirow[t]{2}{*}{ Family labour } & 2631.57 & 2637.05 & 2683.7 & 2771.1 & 2726.831 \\
\hline & $(10.75)$ & $(10.22)$ & $(10.15)$ & $(10.14)$ & $(10.20)$ \\
\hline \multirow[t]{2}{*}{ Hired labour } & 4944.49 & 5230.96 & 5274.86 & 5855.59 & 5597.18 \\
\hline & $(20.19)$ & $(20.26)$ & $(19.96)$ & $(21.43)$ & (20.94) \\
\hline \multirow[t]{2}{*}{ Total human labour cost } & 7576.06 & 7868.01 & 7958.56 & 8626.69 & 8324.011 \\
\hline & $(30.94)$ & $(30.48)$ & $(30.11)$ & $(31.57)$ & $(31.15)$ \\
\hline \multicolumn{6}{|l|}{ C. Power use cost } \\
\hline \multirow[t]{2}{*}{ Bullock labour } & 1239.14 & 1300.05 & 0 & 0 & 219.35 \\
\hline & $(5.06)$ & $(5.04)$ & $(0.00)$ & $(0.00)$ & $(0.82)$ \\
\hline \multirow[t]{2}{*}{ Machine power } & 923.21 & 939.18 & 2234.8 & 2155.36 & 1966.61 \\
\hline & $(3.77)$ & $(3.64)$ & $(8.46)$ & $(7.89)$ & $(7.36)$ \\
\hline \multirow[t]{2}{*}{ Total power use cost } & 2162.35 & 2239.23 & 2234.8 & 2155.36 & 2185.96 \\
\hline & $(8.83)$ & $(8.67)$ & $(8.46)$ & $(7.89)$ & $(8.18)$ \\
\hline \multirow[t]{2}{*}{ Interest on working capital } & 882.73 & 907.19 & 915.67 & 947.53 & 928.34 \\
\hline & $(3.60)$ & $(3.51)$ & $(3.46)$ & $(3.47)$ & $(3.47)$ \\
\hline \multirow[t]{2}{*}{ (I). Total variable cost } & 18477.28 & 19051.16 & 19229.24 & 19898.31 & 19495.18 \\
\hline & $(75.45)$ & $(73.80)$ & $(72.76)$ & $(72.81)$ & $(72.94)$ \\
\hline \multicolumn{6}{|l|}{ D. Fixed cost } \\
\hline \multirow[t]{2}{*}{ Land revenue } & 12 & 12 & 12 & 12 & 12 \\
\hline & $(0.05)$ & $(0.05)$ & $(0.05$ & $(0.04)$ & $(0.04)$ \\
\hline \multirow[t]{2}{*}{ Rental value of land } & 5000 & 5000 & 5000 & 5000 & 5000 \\
\hline & $(20.42)$ & $(19.37)$ & $(18.92)$ & $(18.30)$ & $(18.71)$ \\
\hline \multirow[t]{2}{*}{ Depreciation } & 250 & 850 & 1158 & 1250 & 1136.351 \\
\hline & $(1.02)$ & $(3.29)$ & $(4.38)$ & $(4.57)$ & $(4.25)$ \\
\hline Interest on fixed working capital & $\begin{array}{c}750 \\
(3.06)\end{array}$ & $\begin{array}{c}900 \\
(3.49)\end{array}$ & $\begin{array}{l}1030 \\
(3.90)\end{array}$ & $\begin{array}{l}1168 \\
(4.27)\end{array}$ & $\begin{array}{c}1083.04 \\
(4.05)\end{array}$ \\
\hline \multirow[t]{2}{*}{ (II).Total fixed Cost } & 6012 & 6762 & 7200 & 7430 & 7231.391 \\
\hline & $(24.55)$ & $(26.20)$ & $(27.24)$ & $(27.19)$ & $(27.06)$ \\
\hline Total $\operatorname{cost}(A+B+C+D)$ & 24489.28 & 25813.16 & 26429.24 & 27328.31 & 26726.57 \\
\hline & $(\mathbf{1 0 0})$ & $(\mathbf{1 0 0})$ & $(\mathbf{1 0 0})$ & (100) & $(\mathbf{1 0 0})$ \\
\hline
\end{tabular}

Note: Figures in parentheses indicate percentages of total cost. 
Table.3 Per hectare yield, value of output and cost of production per quintal of Buckwheat

\begin{tabular}{|c|c|c|c|c|c|c|}
\hline S.No. & Particular & Marginal & Small & Medium & Large & Overall \\
\hline $\mathbf{1}$ & $\begin{array}{c}\text { Average yield } \\
\text { (qt1/ha) }\end{array}$ & 19.05 & 20.00 & 20.63 & 21.00 & 20.80 \\
\hline $\mathbf{2}$ & $\begin{array}{c}\text { Average price } \\
\text { (Rs./qt) }\end{array}$ & 4000 & 4000 & 4000 & 4000 & 4000 \\
\hline $\mathbf{3}$ & $\begin{array}{c}\text { Gross returns } \\
\text { (Rs./ha) }\end{array}$ & 76200 & 80000 & 82520 & 84000 & 83200 \\
\hline $\mathbf{4}$ & $\begin{array}{c}\text { Cost of cultivation } \\
\text { (Rs./ha) }\end{array}$ & 24489.28 & 25813.16 & 26429.24 & 27328.31 & 26726.57 \\
\hline $\mathbf{5}$ & $\begin{array}{c}\text { Net returns } \\
\text { (Rs./ha) }\end{array}$ & 51710.72 & 54186.84 & 56090.76 & 56671.59 & 56553.43 \\
\hline $\mathbf{6}$ & $\begin{array}{c}\text { Cost of production } \\
\text { (Rs./qtl.) }\end{array}$ & 1285.53 & 1290.66 & 1281.11 & 1301.35 & 1232.87 \\
\hline $\mathbf{7}$ & Input output ratio & $1: 3.11$ & $1: 3.10$ & $1: 3.12$ & $1: 3.07$ & $1: 3.24$ \\
\hline
\end{tabular}

Table.4 Break-up of total cost and income obtained over different cost of buckwheat cultivation

\begin{tabular}{|c|c|c|c|c|c|}
\hline \multicolumn{1}{|c|}{ Particular } & Marginal & \multicolumn{1}{c|}{$\begin{array}{c}\text { Small } \\
\text { Break-up of costs }\end{array}$} & Medium & Large & Overall \\
\hline & \multicolumn{5}{|c|}{} \\
\hline Cost A1 & 16107.71 & 19913.04 & 20239.24 & 21160.32 & 25643.53 \\
\hline Cost A2 & 21107.71 & 24913.04 & 25399.24 & 26160.32 & 30643.53 \\
\hline Cost B1 & 16857.71 & 20813.04 & 21429.24 & 22328.32 & 26571.87 \\
\hline Cost B2 & 21857.71 & 25813.02 & 26429.24 & 27328.32 & 31571.87 \\
\hline Cost C1 & 19489.28 & 23444.09 & 24112.94 & 25099.42 & 29298.70 \\
\hline Cost C2 & 24489.28 & 28444.09 & 29112.94 & 30099.42 & 28255.4 \\
\hline Cost C3 & 26938.20 & 31288.49 & 32024.23 & 33109.36 & 37729.57 \\
\hline & Return obtained over different costs & & \\
\hline Return over cost A1 & 35333.09 & 34273.92 & 35691.52 & 35511.36 & 30909.90 \\
\hline Return over cost A2 & 30333.09 & 29273.92 & 30691.52 & 30511.36 & 25909.90 \\
\hline Return over cost B1 & 34583.09 & 33373.92 & 34661.52 & 34343.36 & 29981.56 \\
\hline Return over cost B2 & 29583.09 & 28373.92 & 29661.52 & 29343.36 & 24981.56 \\
\hline Return over cost C1 & 31951.52 & 30742.82 & 31977.82 & 31572.26 & 27254.73 \\
\hline Return over cost C2 & 26951.52 & 25742.87 & 26977.82 & 26572.26 & 26556.85 \\
\hline Return over cost C3 & 24502.59 & 22898.46 & 24066.52 & 23562.32 & 23731.31 \\
\hline
\end{tabular}


The cost C2, found to be Rs. 28255.40 per hectare, includes the value of Cost B2 and imputed value of family labour and The Cost C3, found to be Rs. 37729.57 per hectare imputed value of managerial allowances at 10 per cent of cost $\mathrm{C} 2$ return over the Cost $\mathrm{A} 1$, Cost A2, Cost B1, Cost B2, Cost C1, Cost C2, and Cost C3 was obtained to be Rs. 30909.90, Rs. 25909.90, Rs. 29981.56, Rs. 24981.556, Rs. 27254.73, Rs. 26556.85 and Rs. 23731.31, respectively.

\section{The study yielded following major findings}

The total cultivated area per farm was observed to be 0.90 hectare at marginal farm, 1.30 hectare at small farms, 3.00 hectare at medium farms and 5.10 hectare at large farms along with 2.76 hectare as an overall average leading to a high yield.

The government should make adequate arrangement for timely supply of quality seeds and other inputs at reasonable prices to the buckwheat growers to increase the productivity of buckwheat.

The farmers faced the problem of unavailability of labours. Hence, there is a need to bring mechanization in the production

\section{References}

Acharya, S. S., and Agarwal, N. L. (2011). Agricultural marketing in India, 5th eds. Oxford and IBH Publishing $\mathrm{CO}$. Pvt. Ltd., New Delhi.

Arsić, I., Dražić, S., Jevđović, R. (2008): Lekovita svojstva heljde, IX dani lekovitog bilja, 17-20 Septembar, Kosmaj, Zbornik apstrakata, pp. 108109.

Department of agriculture, Government of Chhattisgarh, Raipur, Chattisgarh 2011, www.censusindia.gov.in_2011 census

Directorate of economics and statistics, Raipur, Chhattisgarh, www.agridept. cg.gov.in

Joshi, B. D., and Rana, J. C. (1999). Status of buckwheat in India. Fagopyrum, 16(7), 1.

Popović, V., Sikora, V., Ikanovic, J., Rajičič, V., Maksimović, L., Katanski, S. (2013): Production, productivity and quality of buckwheat in organic growing, pp. 395-404.

Subba Reddy, S., Raghu Ram, P., and Neelakanta Sastry, T. V. Bhavani Devi, I. (2004). Agricultural Economics, Oxford and IBH Publishing Co. Pvt. Ltd., New Delhi.

\section{How to cite this article:}

Aryama Bharti and Prishila Kujur. 2019. Economics of Buckwheat Cultivation in the Mainpat Block of Chhattisgarh. Int.J.Curr.Microbiol.App.Sci. 8(12): 743-751.

doi: https://doi.org/10.20546/ijcmas.2019.812.098 